\title{
Modeling of the composition of ecologically safe clay-gypsum binder
}

\author{
Marat Asamatdinov ${ }^{1}$, Andrey Medvedev ${ }^{1, *}$, Alexey Zhukov $^{1}$, Ervand Zarmanyan ${ }^{1}$ and \\ Alexey Poserenin ${ }^{2}$ \\ ${ }^{1}$ Moscow State University of Civil Engineering, Yaroslavskoye shosse, 26, 129337, Moscow, Russia \\ ${ }^{2}$ Russian State Geological Prospecting University, Miklukcho-Maklaya, 23, 117997, Moscow, Russia
}

\begin{abstract}
Clay-gypsum of each deposit are ecologically safe natural materials. They differ from others in their mineralogical and phase composition, they have different properties. Such a spread of properties of natural clay-gypsum, including after their heat treatment, makes it difficult to process them and, ultimately, use. The factor of "unpredictability of the obtained results" is one of the reasons why this type of natural composites are practically not used in modern construction. The paper presents the results of studies of the properties of model compositions of a clay-gypsum binder. The theoretical basis of the research is the methodology for the creation of new building materials, developed at the MSUCE. According to the proposed provisions, the properties of composite (or multicomponent) systems can be evaluated using the concept of a model body, in our case a "model material", manufactured with observance of certain technological parameters. According to the results of the first stage, the optimum temperature for calcination of an artificial clay-gypsum binder (which was $230-250^{\circ} \mathrm{C}$ ) was established, and a graphical interpretation of the results was carried out using triple diagrams. By results of researches it is established, that the majority of natural structures in the natural state, or after modification can be used as a basis for reception of interior plaster mixes.
\end{abstract}

\section{Introduction}

Construction gypsum is widely used in the construction and production of building materials for products and parts for the preparation of plaster mortars, the production of slabs and panels for partitions, gypsum boards, architectural details, artificial marble, as bases for self-leveling floors and etc.

In the production of building materials (in particular plaster mortars and mixtures for self-leveling floors), plaster compositions containing various mineral components were found on a par with high-quality gypsum binders. As a rule, these are by-products of other industries, less often natural mixtures of natural genesis. By the amount of accumulated experience and the scientific interest in the material, it is possible to isolate phosphogypsum - a by-product of the production of phosphate fertilizers.

*Corresponding author: medvedev747@yandex.ru 
Clay-gypsum (CG), clay-gypsum binder (CGB) and modified clay-gypsum binder (MCGB) are the representatives of this group of gypsum-containing materials by their properties and material composition. Since the basis of these materials is semi-aquatic gypsum, the regularities of its hardening are the determining factor in the formation of the properties of all materials of this group [1-6].

Clay gypsum differs from gypsum, primarily by the amount of impurities that make up $5 \%$ or more. It represents with itself a natural formation of fine-grained crystalline gypsum evenly mixed with clay or loam. The amount of gypsum varies from 50 to $95 \%$. Considering the large "spread" of natural clay gypsum properties of various deposits, it became necessary to create a single scientifically grounded method for obtaining dry mixtures with different amounts of gypsum content.

\section{Materials and Methods}

In construction materials science, composite construction materials are considered as systems that allow systems with the highest quality indicators to be obtained on the basis of integrating the properties of individual components; while distinguishing both natural composites and artificial ones. Clay gypsums belong to natural composites, and earlier studies suggest that the clay-gypsum binder can be considered as an independent type of astringent air substance, and under certain modification conditions, and hydraulic hardening [7-10].

The theoretical basis of this method was the methodology for creating new building materials, developed at the MSUCE under the guidance of Professor B.M. Rumyantsev. According to the proposed provisions, the properties of composite (or multicomponent) systems can be evaluated using the concept of the model body [11-14], in our case - the "model material", manufactured with observance of certain technological parameters.

The composition of the "model material" used pure gypsum of the Peshelansky deposit of the Nizhny Novgorod region, montmorillonite clay, quartz sand, additives. Tests of the properties of clay gypsum were carried out in accordance with GOST 23789-79.

The implementation of the concept of "model clay gypsum" suggested answers to the following questions:

1) at what quantity of admixtures of clay, sand, etc., it is possible to obtain an astringent of clay gypsum;

2) determine the optimal heat treatment regimes for clay gypsum and its grinding parameters;

3) determine the types and costs of modifying additives introduced to correct (reduce) the water requirement of the binder.

\section{Results and discussion}

The experiment was carried out in two stages. At the first stage, the clay-gypsum model compositions (artificial clay-gypsum binder) with gypsum content from 30 to $70 \%$ were investigated; clay consumption 10-35\% and sand consumption from 10 to $60 \%$ (Figure 1, area I). The firing temperature ranged from 180 to $250^{\circ} \mathrm{C}$. The results of the experiments are given in Table 1.

According to the results of the first stage, the optimum temperature for calcination of an artificial clay-gypsum binder (which was $230-250^{\circ} \mathrm{C}$ ) was established, and a graphic interpretation of the results was also carried out. Since the system under investigation is, in fact, triple, the graphic interpretation and the relationship of components and results was carried out using triple diagrams (Fig. 1). 
Table 1. Compositions of plaster mixtures on the basis of model clay-gypsum binder (mCGB) and modifiers.

\begin{tabular}{|c|c|c|c|c|c|c|c|}
\hline \multirow[t]{2}{*}{ CG compositions } & \multirow[t]{2}{*}{$\mathrm{W} / \mathrm{R}^{*}$} & \multicolumn{2}{|c|}{ Setting time, $\min$} & \multicolumn{3}{|c|}{$\begin{array}{l}\text { Compressive strength, } \\
\text { MPa, days through }\end{array}$} & \multirow[t]{2}{*}{$\begin{array}{l}\text { Coefficient of } \\
\text { softening }\end{array}$} \\
\hline & & start & end & 3 & 7 & 28 & \\
\hline $\begin{array}{l}50 \% \text { gypsum in } \\
\mathrm{mCGB}+5 \% \text { PC }\end{array}$ & 0,32 & 68 & 80 & 5,2 & 5,9 & 7,1 & 0,38 \\
\hline $\begin{array}{l}50 \% \text { gypsum in } \\
\mathrm{mCGB}+7 \% \text { PC }\end{array}$ & 0,3 & 76 & 89 & 4,7 & 6,2 & 7,6 & 0,26 \\
\hline $\begin{array}{l}50 \% \text { gypsum in } \\
\mathrm{mCGB}+10 \% \mathrm{PC}\end{array}$ & 0,26 & 82 & 94 & 5,5 & 6,9 & 8,6 & 0,23 \\
\hline $\begin{array}{l}50 \% \text { gypsum in } \\
\mathrm{mCGB}+5 \% \text { PC }\end{array}$ & 0,42 & 52 & 66 & 2,7 & 4,2 & 4,9 & 0,31 \\
\hline $\begin{array}{l}40 \% \text { gypsum in } \\
\mathrm{mCGB}+7 \% \text { PC }\end{array}$ & 0,35 & 65 & 81 & 1,7 & 3,2 & 3,4 & 0,3 \\
\hline $\begin{array}{l}40 \% \text { gypsum in } \\
\mathrm{mCGB}+10 \% \mathrm{PC}\end{array}$ & 0,3 & 76 & 92 & 2,9 & 4,6 & 4,8 & 0,3 \\
\hline $\begin{array}{l}30 \% \text { gypsum in } \\
\text { mCGB }+5 \% \text { PC }\end{array}$ & 0,3 & 55,19 & 71,40 & 1,6 & 2,4 & 3,3 & 0,22 \\
\hline $\begin{array}{l}30 \% \text { gypsum in } \\
\mathrm{mCGB}+7 \% \text { PC }\end{array}$ & 0,28 & 59,13 & 80,15 & 2,2 & 3,3 & 4,0 & 0,23 \\
\hline $\begin{array}{l}30 \% \text { gypsum in } \\
\mathrm{mCGB}+10 \% \mathrm{PC}\end{array}$ & 0,28 & 64,12 & 83,11 & 2,3 & 3,5 & 4,2 & 0,25 \\
\hline
\end{tabular}

* The water-cement ratio corresponding to the normal density of the mud-gypsum mixture (model, modified); mCGB - model clay-gypsum binder; PC - portland cement.

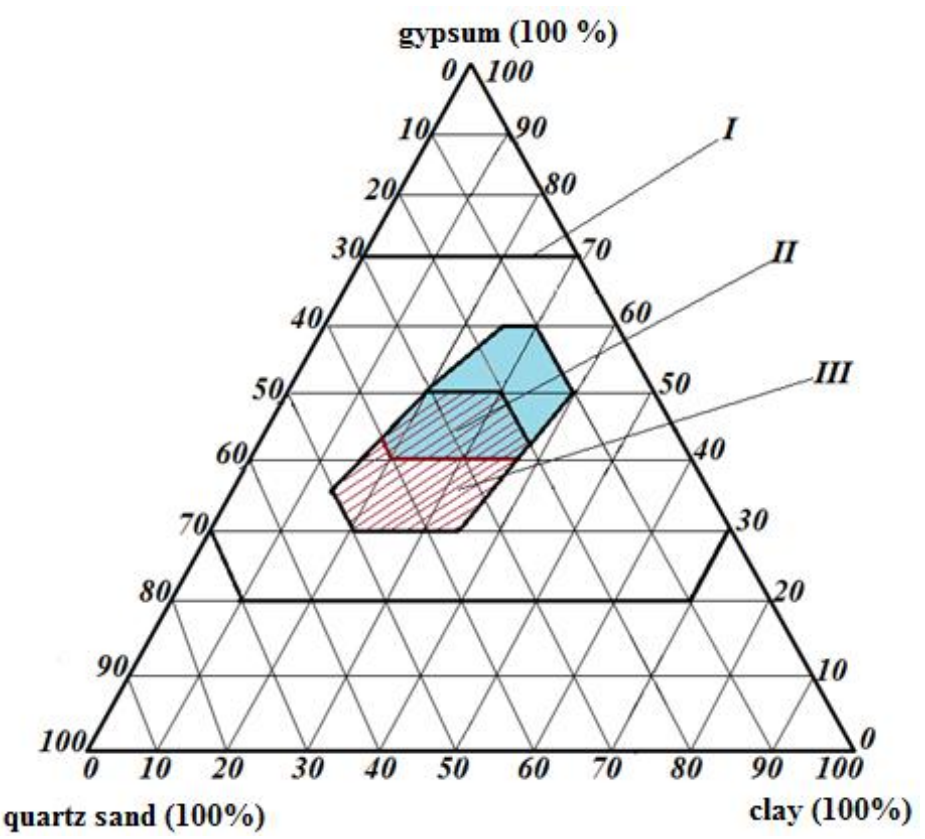

Fig. 1. Diagram of the state of the model clay-gypsum binder (CGB): I - area of the experiment; II area of optimal relations of the model CGB; III - area of optimal relations for a modified model CGB.

The region of optimal compositions established in the experiment (Figure 1, area II), proves the use of formulations that allow obtaining products with strength at the age of 7 days of at least 6.0 MPa. the setting time was as follows: start - from 12 minutes, end - up 
to 18 minutes; at an interval of 2-3 minutes. The water-hard ratio was $0,5-0,7$; softening factor $0,05-0,15$.

The strength of the model binder completely satisfied the requirements of GOST, but a short interval of setting, as well as a high water flow did not provide the necessary technological ability to produce plaster compositions. This became the basis for the second series of experiments on a model binder with modification of its additives. At the second stage, the clay-gypsum compositions were modified with additions of portland cement (5$10 \%), \mathrm{C}-3(1,0 \%)$, citric acid $(0,07 \%)$. The results of the experiments are presented in tables 2 and 3.

Table 2. The change in the strength characteristics of the clay-gypsum binder by introducing superplasticizer C-3.

\begin{tabular}{|c|c|c|c|c|c|c|c|c|c|c|c|}
\hline \multirow{2}{*}{$\begin{array}{l}\text { Composi } \\
\text { tions CG } \\
\text { with the } \\
\text { addition } \\
\text { of C-3 }\end{array}$} & \multirow{2}{*}{$\mathrm{W} / \mathrm{R}$} & \multicolumn{2}{|c|}{$\begin{array}{l}\text { Setting time, } \\
\text { min }\end{array}$} & \multicolumn{6}{|c|}{$\begin{array}{l}\text { Compressive strength, } \\
\text { cube } 4 \times 4 \times 4 \mathrm{~cm}\end{array}$} & \multirow{2}{*}{$\begin{array}{l}\text { Coeffici } \\
\text { ent of } \\
\text { softenin } \\
\text { g } \\
7 \text { days }\end{array}$} & \multirow{2}{*}{$\begin{array}{c}\text { Densit } \\
\mathrm{y}\end{array}$} \\
\hline & & start & end & $2 \mathrm{~h}$ & $\begin{array}{c}1 \\
\text { days }\end{array}$ & $\begin{array}{c}3 \\
\text { days }\end{array}$ & $\begin{array}{c}7 \\
\text { days }\end{array}$ & $\begin{array}{c}14 \\
\text { days }\end{array}$ & $\begin{array}{c}28 \\
\text { days }\end{array}$ & & \\
\hline CG100\% & 0,53 & 13,1 & 18,42 & 3,6 & 3,7 & 3,9 & 7,5 & 7,8 & 8,0 & 0,4 & 1318 \\
\hline $\begin{array}{c}\mathrm{CG} \\
+0,4 \%\end{array}$ & 0,47 & 29,4 & 33,25 & 3,7 & 3,8 & 4,2 & 7,6 & 7,9 & 8,1 & 0,44 & 1348 \\
\hline $\begin{array}{c}\mathrm{CG} \\
+0,8 \%\end{array}$ & 0,43 & 29,15 & 34,00 & 4,0 & 5,0 & 5,8 & 7,9 & 8,2 & 8,4 & 0,43 & 1404 \\
\hline $\mathrm{CG}+1 \%$ & 0,41 & 32,20 & 36,40 & 4,4 & 5,1 & 6,3 & 9,1 & 9,3 & 9,4 & 0,42 & 1391 \\
\hline $\begin{array}{c}\mathrm{CG} \\
+1,2 \% \\
\end{array}$ & 0,41 & 34,45 & 38,20 & 4,6 & 5,0 & 6,8 & 9,4 & 9,6 & 9,7 & 0,44 & 1415 \\
\hline
\end{tabular}

Table 3. Properties of plaster mixtures with complex modification.

\begin{tabular}{|c|l|c|c|c|c|c|}
\hline \multirow{2}{*}{ Compositions of the mixtures } & \multirow{2}{*}{ W/R } & \multicolumn{2}{c|}{ Setting time, min } & \multicolumn{2}{c|}{ Strength, in 7 days } \\
\cline { 4 - 7 } & & start & end & bend & $\begin{array}{c}\text { compressi } \\
\text { on }\end{array}$ \\
\hline 1 & CG $+0,4 \%$ C-3+0,05\%CA & 0,47 & 52 & 57 & 2,5 & 5,0 \\
\hline 2 & CG $+0,8 \%$ C-3+0,05\% CA & 0,43 & 71 & 77 & 3,7 & 5,5 \\
\hline 3 & CG $+1 \%$ C-3+0,05\% CA & 0,41 & 73 & 80 & 2,6 & 5,9 \\
\hline 4 & CG $+1,2 \%$ C-3+0,05\% CA & 0,41 & 50 & 53 & 3,6 & 7,8 \\
\hline
\end{tabular}

Note: according to GOST $31377-2008$, the quality indicators of the solidified mixtures were determined at the age of 7 days. C-3 - superplasticizer C-3. CA - citric acid.

As shown in the above tables and diagram, even at $30 \%$ of the gypsum content in the artificial modified clay-gypsum composition at 28 days hardening, the minimum strength is 3.0 $\mathrm{MPa}$, and at 7 days hardening 2,7 MPa. Based on the experiment results, the region of the optimal modified compositions was determined (see Figure 1, region III, selected by hatching).

Most natural compositions of clay-gypsum are in the combined area II + III, that is, it can be concluded that most of the natural formulations in their natural state, or after modification, can be used as a basis for obtaining interior plaster mixtures.

The content of gypsum in building clay to obtain binder should be at least $40 \%$ of CaSO4. With further modification to obtain stucco solutions with the addition of Portland cement in an amount of $10 \%$ should be at least $30 \%$ of $\mathrm{CaSO}_{4}$ (allowed). The optimum heat treatment interval is $180-230^{\circ} \mathrm{C}$. Plaster compositions based on modified clay gypsum have a sufficiently long setting interval and can be applied both manually and mechanically.

The clay-gypsum has the following phase composition, $\%$ of mass: two-water gypsum 1,8 ; semi-aquatic gypsum - 70,3; quartz - 11,1; albite $-8,6$; calcite - 6.1; kaolinite - 2,1. With an increase in the heat treatment temperature of up to $300^{\circ} \mathrm{C}$, traces of anhydrite are detected with a proportional decrease in the proportion of the two-water gypsum. 
The results of X-ray phase analysis (Figure 2) show that although the sample was subjected to firing at $250^{\circ} \mathrm{C}$, there is no Anhydrite II in the composition, which should have been formed, with the presence of a double-water gypsum that should not be present in the system. Presumably, the clay locally or over the entire volume does not allow the material to fully dehydrate in the process of calcination, as it clots and envelops the gypsum.

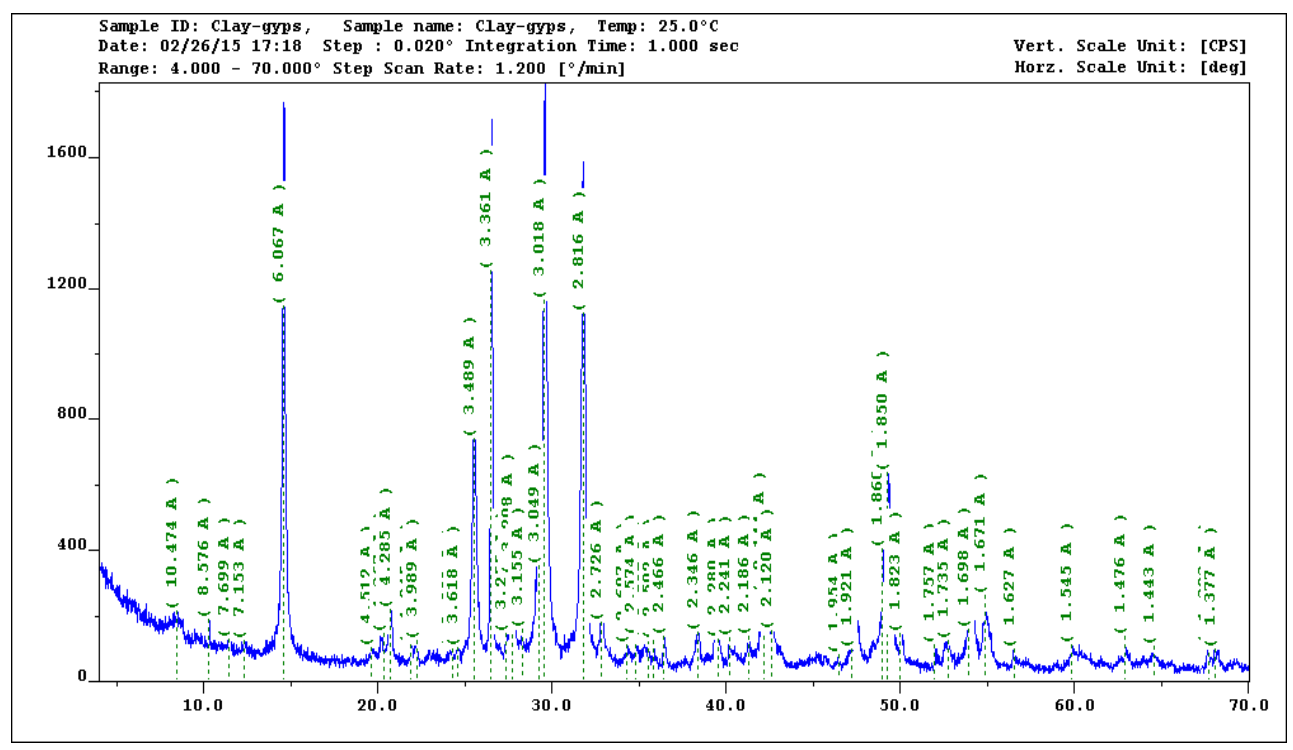

Fig. 2. Processed diffractogram of clay gypsum.

The products of the thermal decomposition of clay gypsum with a substance of the same chemical nature, calcium sulphate, but with different dissolution rates, are of interest for studying the role of these processes in the structure formation.

The introduction of a superplasticizer into the binder leads to a change in the strength characteristics of the hardened clay gypsum stone, as well as to the modification of the conditions for the formation of the material structure. Molecules of plasticizer, sorbing on the surfaces of clay particles, create hydrophobic layers, which changes the equilibrium of states on the boundary "gypsum binding-clay minerals-water".

To extend the setting time, citric acid was added to the modified clay-gypsum binder with superplasticizer C-3. The addition of citric acid together with the addition of a superplasticizer provided the normative terms of setting the plaster solution. According to regulatory requirements, start of setting of plaster solutions should come from the moment of water quenching no earlier than 45 minutes in the course of work (preparation of mixtures and their application by hand).

\section{Conclusion}

In connection with the widespread use of building gypsum in the production of building materials, various requirements are imposed on it, the most important of which is high strength and the ability to regulate within a wide range of setting time. The setting time has a great importance for the practice of using construction gypsum in construction for manufacturers and applications of dry construction mixtures.

It is established that the clay gypsum has several advantages in front of the plaster and molding plaster, namely: the clay gypsum plaster is smooth, without pores, it has a pleasant 
texture, is durable and does not fear water, work with it is more convenient - gripping starts slower than gypsum. Of particular interest is the clay-gypsum binder for regions where there is no production of mineral binders, and the existing deficit is covered by imports.

\section{References}

1. B. Rumiancev, Technology decorative and acoustic materials, Textbook (MGSU, Moscow, 2010)

2. V. Korovjakov, Increasing the effectiveness of producing and using gypsum materialsand products: mat. of the All-Russ. Seminar, RAASN, 51-56 (2002)

3. I. Bessonov, Increasing the effectiveness of producing and using gypsum materials and products: mat. Of the All-Russ. Seminar, RAASN, 82-87 (2002)

4. A. Zhukov, V. Korovyakov, M. Asamatdinov, A. Chkunin, G. Rumyantsev, Scientific Review 7, 86-90 (2016)

5. B. Rumiantcev, A. Zhukov, A. Orlov, Decorative and acoustic gypsum-containing materials, Monograph (MGSU, Moscow, 2014)

6. V. Telichenko, D. Oreshkin, Ecology of urbanized areas 2, 31-33 (2015)

7. H. Zhuk, A. Zhukov, Ecology and industry of Russia 4, 52-57 (2018)

8. B. Rumiantcev, A. Zhukov, D. Zelenshikov, A. Chkunin, K. Ivanov, Y. Sazonova, MATEC Web of Conferences 86 (2016)

9. A. Zhukov, E. Bobrova, D. Zelenshchikov, R. Mustafaev, A. Khimich Insulation systems and green sustainable construction, Adv. Mat., Str. and Mech. Engineering 1025 - 1026, 1031-1034 (2014)

10. B. Rumiantcev, A. Zhukov, E. Bobrova, I. Romanova, D. Zelenshikov, T. Smirnova MATEC Web of Conferences 86 (2016)

11. A Zhukov, I. Bessonov, A. Sapelin, N. Naumova, A. Chkunin, Italian Science Review 2, 155-157 (2014)

12. B. Rumjancev, A. Zhukov, VolgGASU Internet-herald 3 (2012)

13. B. Rumyancev, A. Zhukov, E. Bobrova, T. Smirnova, Industrial and civil building 1, 32-36 (2015)

14. V. Sokov, A. Beglyarov, D. Zemlyanushnov, D. Zhabin, Bulletin MSUCE 1-2, 309$312(2011)$ 